\title{
WHAT CAN A COUNTRY DO TO GET MORF, AID?
}

\section{Helen Eisen and John White*}

The statistical work summarised in this paper was undertaken by Helen Eisen, to test a hypothesis advanced by John White in a recently published book (The Politics of Foreign Aid, Bodley Head, 1974), to the effect that there is a regularity in flows of aid associated with certain types of historical situations. It seems clear from the findings of this work that the original hypothesis is valid only for a severely limited number of cases, and that the range of actions which a country can effectively take to attract more aid, or even to maintain aid at an assured level, is narrower than is commonly supposed. In particular, the work shows an exceptional degree of volatility in the flow of aid to Latin American countries, which these countries seem relatively powerless to affect.

Although the paper is in some respects critical of certain claims made by the Development Assistance Committee of the OECD, it should be clear that the authors are deeply indebted to the DAC for the increasing precision and detail of its aid statistics, without which an analysis of the kind presented here would not be possible. The authors also wish to thank Robert Cassen and Michael Lipton for useful comments on an earlier draft.

\section{Introduction}

Studies of the geographical distribution of aid have in general been concerned with classes of countries, compared on a world-wide basis, and have focused attention on the question: why do some countries get more aid, in relation to their size, than others?' ${ }^{1}$ The standard approach is to take per capita aid receipts, either for a single year or averaged over a period (seldom more than three years), and to correlate these receipts with various putative explanatory variables. The massively uniform conclusion of such studies is summed up by Mikesell: "It is impossible to discern any economic rationale for the distribution of aid, either overall or by agency or by donor country" (Mikesell, 1968). The conclusion is the same whether one takes the

*Helen Eisen was a Research Officer at the IDS in 1972. John White is a Fellow of the Institute of Development Studies.

${ }^{1}$ See footnote on following page. 
figures for total financial flows or only official development assistance, whether one takes aid from all sources or only from bilateral donors, whether one takes figures for commitments, gross disbursements, net disbursements or the net transfer. High aid receipts are associated, not with need in any developmental sense, but with the donors' pursuit of commercial or strategic interests, and with a special relationship between donors and recipients, notably the relationship of colonial dependency (DAC 1969 Review).

Statistically, the two variables most closely associated with variations in aid receipts, as presented in the most familiar studies, are size of country - the well established 'small country effect', which gives countries with small populations higher per capita receipts than countries with large populations - and what the DAC terms the 'inertial element', which shows up as a very strong correlation between aid flows to recipients in different years. The DAC has laid special emphasis on inertia in aid flows: the tendency of countries to receive this year, relatively speaking, more or less what they received

${ }^{1}$ The most extensive discussion of geographical distribution in these terms is to be found in successive publications of the Organization for Economic Co-operation and Development (OECD), in particular:

(i) OECD The Flow of Financial Resources to Less-developed Countries 1961-1965, Paris, 1967, chapter VII;

(ii)OECD Development Assistance: Efforts and Policies of the Members of the Development Assistance Committee: 1968 Review, Paris, 1969, chapter VII (hereafter, DAC 1968 Review);

(iii) OECD Development Assistance: Efforts and Policies of the Members of the Development Assistance Committee: 1969 Review, Paris, 1970, chapter V (hereafter, DAC 1969 Review).

Other studies using the same approach tend to draw heavily on the DAC's statistical work, as does this paper. An early example is I.M.D. Little and J.M. Clifford, International Aid: A Discussion of the Flow of Public Resources from Rich to Poor Countries, with Particular Reference to British Policy, Allen and Unwin, 1965. Data for commitments rather than disbursements are analysed, using similar methods and reaching similar conclusions, in P.D. Henderson, 'The Distribution of Official Development Assistance Commitments by Recipient Countries and by Sources', Bulletin: Oxford University Institute of Economics and Statistics, vol. 33, no. 1, February 1971. Most of the general studies of the economics of foreign aid include a chapter which follows more or less the same lines: e.g. Raymond F. Mikesell, The Economics of Foreign Aid, Weidenfeld and Nicolson, 1968, Chapter Nine; David Wall, The Charity of Nations: The Political Economy of Foreign Aid, Macmillan, 1973, chapter VIII; John White, The Politics of Foreign Aid, Bodley Head, 1974, chapter II; etc. 
last year, with the conclusion that this "would seem to allay the apprehension of less-developed countries that the amounts of aid they receive are not predictable for more than one year ahead" (DAC 1969 Review).

Perhaps because of a measure of complacency induced by the assumption of inertia, studies of the geographical distribution of aid have paid relatively little attention to the question of changes over time. This is a serious omission. Given the aim of most governments of developing countries to increase their aid receipts, coupled with their fears of a reduction in these receipts, identification of the factors which cause changes over time would seem to have greater operational relevance than static inter-country comparisons. The focus on inter-country comparisons would seem to be yet another manifestation of the predominance of a donor-oriented perspective in the aid literature.

A second omission is the failure to explain variations within each category. The concentration on very small countries in aid-giving is not necessarily significant if it does not use up large absolute amounts. In terms of the numbers of people affected and the volume of resources committed, the fact that the per capita resource flow to India in 1972 was one-fiftieth of the per capita flow to Malta is less significant than the fact that it was one-fifth of the per capita flow to Indonesia and one-eleventh of the flow to Brazil (DAC $1973 \mathrm{Re}$ view). Operationally, comparing widely disparate countries may be less useful than comparing like with like.

In an attempt to fill this gap in the literature, we have analysed changes in the volume of aid to individual countries during the 1960 s. Taking the assumption of inertia as our starting point, we expected to be able to trace the flow of aid for each country back to some specific event in time which had set the volume at a continuing level, and our hope was that we would be able to classify these events in such a way as to give individual developing countries a reasonably clear picture of the circumstances under which they could expect a significant increase or decrease in their relative aid receipts. More formally, the hypothesis to be tested was of the form:

A change in the annual flow of aid to a country in excess of $\mathrm{X}$ per cent will be associated with events of types $A, B$ and $C$, and in the absence of further events of these types subsequent 
changes in volume will not exceed $Y$ per cent for $Z$ years.

As will be seen, the pattern sketched in this hypothesis, with sharp changes in response to specific events followed by periods of relative stability, was not found to be general. It would follow that the interpretation put upon the appearance of inertia by the DAC, suggesting that the distribution of aid, however 'irrational' is at least predictable, is indeed too complacent.

The analysis was confined to major recipients, defined as countries with populations of more than four million receiving annual average commitments of official development assistance in the period 1967-69 in excess of $\$ 30$ million. There were 39 such countries. One reason for confining the analysis to major recipients was to avoid distortions arising from large relative changes in small absolute amounts. Another was to focus attention on what we saw as the main problem, that of countries with large numbers of very poor people receiving relatively small amounts of aid. The data used initially were for gross bilateral disbursements by DAC member countries.

Disbursements rather than commitments were chosen for three reasons: first, because the former are more easily comparable over the period; second, because many aid agencies plan on the basis of likely disbursements, and tailor their commitments accordingly; third, because disbursements are 'real', whereas commitments sometimes turn out to lack substance.

We confined ourselves to 'Western' (i.e. DAC) bilateral donors, as constituting a relatively homogeneous group. One possibility to be considered was that increases in aid from the centrally planned economies were a major stimulant. Also, we wanted to know whether multilateral agencies were free of the preoccupations of bilateral donors, as is commonly claimed, perhaps even consciously performing a compensatory function to offset the vagaries of the bilateral donors, or whether on the contrary they moved in step. (As will be seen, we found the latter to be generally the case). Both of these questions would have been obscured if we had started with total flows from all sources. For the centrally planned economies, we also had a problem arising from the fact that only commitment data are available. 
Somewhat similar considerations governed our use of gross rather than net data. Gross disbursements reflect most accurately the outcome of current decisions. It is possible that one factor in these decisions is the need to offset increases in debt servicing, in which case variations in the net transfer should be found to be less than variations in the gross flow. This possibility would be obscured if one took net figures at the outset. (In fact, the figures give little support to the belief that the net transfer looms large in donors' calculations. Average fluctuations in the net flow are greater than fluctuations in the gross flow).

\section{Patterns of Change}

Table 1 shows gross bilateral disbursements to the 39 countries in the table 1

Gross bilateral (DAC) disbursements to 39 major recipients, 1961-70 US \$ million

\begin{tabular}{|c|c|c|c|c|c|c|c|c|c|c|}
\hline country & 1961 & 962 & 1963 & 1964 & 1965 & 1966 & 1967 & 1968 & 1969 & 1970 \\
\hline $\begin{array}{l}\text { Algeria } \\
\text { Morocco } \\
\text { Tunisia } \\
\text { United Arab Republic } \\
\text { Cameroon } \\
\text { Zaire } \\
\text { Ethiopia } \\
\text { Ghana } \\
\text { Ivory Coast } \\
\text { Kenya } \\
\text { Madagascar } \\
\text { Malawi } \\
\text { Nigeria } \\
\text { Tanzania } \\
\text { Uganda } \\
\text { Zambia } \\
\text { Dominican Republic } \\
\text { Guatemala } \\
\text { Mexico } \\
\text { Argentina } \\
\text { 8olivia } \\
\text { Brazil } \\
\text { Chile } \\
\text { Colombia } \\
\text { Peru } \\
\text { Venezuela } \\
\text { Turkey } \\
\text { Iran } \\
\text { Afghanistan } \\
\text { Ceylon } \\
\text { India" } \\
\text { Pakistan* } \\
\text { Taiwan } \\
\text { Indonesia } \\
\text { South Korea } \\
\text { Malaysiat } \\
\text { Philippines } \\
\text { Thailand } \\
\text { South Vietnam } \\
\text { Mon to }\end{array}$ & \begin{tabular}{|r|}
453.70 \\
134.34 \\
92.17 \\
123.61 \\
7 \\
60.22 \\
21.17 \\
2.61 \\
1 \\
63.69 \\
7 \\
8.37 \\
33.46 \\
40.29 \\
21.14 \\
1.26 \\
$\$$ \\
15.00 \\
116.07 \\
101.69 \\
23.09 \\
321.35 \\
141.78 \\
73.01 \\
11.43 \\
29.01 \\
198.50 \\
138.82 \\
38.39 \\
11.99 \\
648.38 \\
260.60 \\
120.02 \\
121.31 \\
229.52 \\
21.36 \\
56.17 \\
28.73 \\
166.76
\end{tabular} & $\begin{array}{r}403.41 \\
98.00 \\
69.60 \\
188.76 \\
114.25 \\
11.25 \\
25.72 \\
5.59 \\
7 \\
49.02 \\
7 \\
11.74 \\
31.81 \\
47.65 \\
28.47 \\
5.88 \\
22.00 \\
9.01 \\
69.52 \\
110.21 \\
31.68 \\
201.13 \\
150.10 \\
63.04 \\
31.22 \\
89.02 \\
240.74 \\
65.32 \\
17.26 \\
12.78 \\
689.99 \\
387.73 \\
82.05 \\
166.39 \\
235.73 \\
22.88 \\
42.44 \\
38.19 \\
175.78\end{array}$ & $\begin{array}{r}279.86 \\
98.52 \\
81.85 \\
208.78 \\
1 \\
104.39 \\
22.76 \\
17.76 \\
7 \\
55.71 \\
\$ \\
16.62 \\
22.43 \\
31.17 \\
20.51 \\
5.43 \\
47.04 \\
10.11 \\
53.10 \\
92.88 \\
46.90 \\
223.65 \\
151.46 \\
93.58 \\
30.46 \\
48.18 \\
233.35 \\
44.88 \\
36.88 \\
10.95 \\
934.35 \\
494.12 \\
78.96 \\
118.91 \\
249.01 \\
18.86 \\
29.71 \\
35.11 \\
227.03\end{array}$ & $\begin{array}{r}229.72 \\
84.21 \\
70.05 \\
241.12 \\
23.24 \\
107.32 \\
12.65 \\
19.86 \\
34.70 \\
57.99 \\
38.05 \\
32.61 \\
46.59 \\
42.67 \\
21.51 \\
20.77 \\
23.03 \\
12.64 \\
79.56 \\
93.60 \\
36.19 \\
259.14 \\
139.39 \\
63.11 \\
39.49 \\
27.39 \\
168.36 \\
24.90 \\
46.22 \\
9.21 \\
169.20 \\
504.45 \\
52.66 \\
82.39 \\
168.87 \\
19.13 \\
80.50 \\
32.77 \\
245.37\end{array}$ & $\begin{array}{r}148.51 \\
109.22 \\
91.35 \\
124.70 \\
25.21 \\
136.21 \\
17.03 \\
45.49 \\
31.25 \\
71.62 \\
41.12 \\
34.76 \\
70.71 \\
35.79 \\
20.29 \\
13.61 \\
79.35 \\
14.71 \\
83.59 \\
58.93 \\
31.68 \\
257.85 \\
125.15 \\
80.20 \\
73.78 \\
38.79 \\
191.90 \\
38.10 \\
53.07 \\
15.30 \\
1198.01 \\
464.60 \\
54.97 \\
57.19 \\
223.22 \\
24.45 \\
98.18 \\
49.14 \\
315.01\end{array}$ & $\begin{array}{r}127.79 \\
90.88 \\
70.29 \\
89.24 \\
27.92 \\
89.68 \\
32.62 \\
79.71 \\
39.53 \\
58.21 \\
34.57 \\
31.11 \\
74.77 \\
37.75 \\
24.84 \\
34.28 \\
53.37 \\
10.08 \\
100.85 \\
91.07 \\
25.87 \\
337.66 \\
141.20 \\
90.11 \\
75.43 \\
47.84 \\
185.85 \\
43.00 \\
51.36 \\
34.03 \\
1190.48 \\
356.05 \\
43.37 \\
89.55 \\
215.76 \\
30.16 \\
61.07 \\
54.20 \\
513.42\end{array}$ & $\begin{array}{r}108.11 \\
69.10 \\
104.80 \\
52.27 \\
28.11 \\
93.86 \\
25.66 \\
71.92 \\
34.29 \\
41.61 \\
34.26 \\
29.64 \\
77.51 \\
31.35 \\
21.23 \\
70.92 \\
64.32 \\
18.41 \\
114.29 \\
80.21 \\
28.73 \\
224.66 \\
117.15 \\
105.07 \\
56.47 \\
52.56 \\
172.13 \\
64.64 \\
38.66 \\
48.60 \\
1239.51 \\
446.31 \\
87.09 \\
259.22 \\
272.27 \\
28.04 \\
112.13 \\
68.28 \\
458.75\end{array}$ & $\begin{array}{r}17.06 \\
111.05 \\
76.23 \\
55.20 \\
30.80 \\
68.84 \\
38.36 \\
85.66 \\
40.20 \\
43.46 \\
31.75 \\
23.26 \\
75.09 \\
29.33 \\
19.01 \\
54.68 \\
50.39 \\
21.14 \\
156.50 \\
43.22 \\
50.87 \\
295.61 \\
203.33 \\
113.17 \\
50.67 \\
42.57 \\
188.95 \\
118.02 \\
25.99 \\
48.60 \\
1010.61 \\
435.81 \\
85.12 \\
338.51 \\
304.61 \\
55.21 \\
119.18 \\
82.83 \\
447.99\end{array}$ & $\begin{array}{r}99.66 \\
91.41 \\
111.74 \\
20.36 \\
31.82 \\
75.00 \\
33.52 \\
76.94 \\
46.17 \\
46.13 \\
31.75 \\
22.81 \\
88.10 \\
31.68 \\
20.28 \\
23.95 \\
40.23 \\
14.46 \\
91.22 \\
73.79 \\
37.11 \\
237.27 \\
159.81 \\
124.70 \\
66.40 \\
57.98 \\
184.11 \\
100.55 \\
24.77 \\
54.87 \\
838.06 \\
340.68 \\
86.60 \\
346.34 \\
435.21 \\
55.62 \\
155.67 \\
122.28 \\
464.54\end{array}$ & $\begin{array}{r}120.69 \\
113.30 \\
111.74 \\
57.77 \\
43.60 \\
86.50 \\
35.27 \\
59.65 \\
57.13 \\
58.15 \\
32.08 \\
27.19 \\
96.81 \\
41.37 \\
26.57 \\
16.46 \\
41.80 \\
14.72 \\
126.29 \\
84.98 \\
24.07 \\
248.34 \\
117.64 \\
147.02 \\
78.75 \\
41.44 \\
176.43 \\
104.06 \\
26.41 \\
56.56 \\
901.86 \\
433.03 \\
72.30 \\
530.72 \\
373.06 \\
36.84 \\
166.27 \\
136.37 \\
436.33\end{array}$ \\
\hline
\end{tabular}

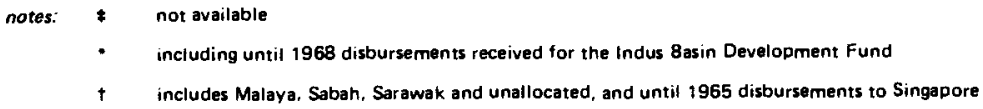

source: OECD, Geographical Distribution of Financial Flows to Less Developed Countries, 1960-64, 1965 and 1966/67. and unpublished data for subsequent years. 
table 2

Annual percentage shift in gross bilateral (DAC) disbursements to 39 major recipients, 1961/62 to 1969/70

\begin{tabular}{|c|c|c|c|c|c|c|c|c|c|}
\hline country & $1961-62$ & $1962-63$ & $1963-64$ & $1964-65$ & $1965-66$ & $1966-67$ & $1967-68$ & $1968-69$ & $1969-70$ \\
\hline $\begin{array}{l}\text { Algeria } \\
\text { Morocco } \\
\text { Tunisia } \\
\text { United Arab Republic } \\
\text { Cameroon } \\
\text { Zaire } \\
\text { Ethiopia } \\
\text { Ghana } \\
\text { Ivory Coast } \\
\text { Kenya } \\
\text { Madagascar } \\
\text { Malawi } \\
\text { Nigeria } \\
\text { Tanzania } \\
\text { Uganda } \\
\text { Zambia } \\
\text { Dominican Republic } \\
\text { Guatemala } \\
\text { Mexico } \\
\text { Argentina } \\
\text { Bolivia } \\
\text { Brazil } \\
\text { Chile } \\
\text { Colombia } \\
\text { Peru } \\
\text { Venezuela } \\
\text { Turkey } \\
\text { Iran } \\
\text { Afghanistan } \\
\text { Ceyion } \\
\text { India } \\
\text { Pakistan } \\
\text { Taiwan } \\
\text { Indonesia } \\
\text { South Korea } \\
\text { Malavsia } \\
\text { Philippines } \\
\text { Thailand } \\
\text { South Vietnam }\end{array}$ & $\begin{array}{c}-11.1 \\
-27.1 \\
-24.5 \\
+34.5 \\
+ \\
+47.3 \\
+17.7 \\
+53.3 \\
+ \\
-23.0 \\
+ \\
+28.7 \\
-4.9 \\
+15.4 \\
+25.7 \\
+78.6 \\
+ \\
-39.9 \\
-40.1 \\
+7.7 \\
+27.1 \\
-37.4 \\
-55.5 \\
-13.7 \\
-63.4 \\
+67.4 \\
+17.5 \\
-52.9 \\
-55.3 \\
+6.2 \\
+6.0 \\
+32.8 \\
-31.6 \\
+27.1 \\
+2.6 \\
+6.6 \\
-24.4 \\
+24.8 \\
+5.1\end{array}$ & $\begin{array}{c}+0.5 \\
+15.0 \\
+9.6 \\
t \\
-8.6 \\
-11.5 \\
+68.5 \\
t \\
+12.0 \\
+ \\
+29.4 \\
-35.8 \\
-34.6 \\
-28.0 \\
-7.7 \\
+53.2 \\
+10.9 \\
-23.6 \\
-15.7 \\
+32.5 \\
+10.1 \\
+0.9 \\
+32.6 \\
--2.4 \\
-45.9 \\
-3.1 \\
-31.3 \\
+53.2 \\
-14.3 \\
+26.2 \\
+21.5 \\
-3.8 \\
-28.5 \\
+5.3 \\
-17.6 \\
-30.0 \\
-8.1 \\
+22.6\end{array}$ & $\begin{array}{r}-17.9 \\
-14.5 \\
-14.4 \\
+13.4 \\
t \\
+\quad 2.7 \\
-44.4 \\
+\quad 10.6 \\
+ \\
+\quad 3.9 \\
+ \\
+49.0 \\
+51.9 \\
+27.0 \\
+\quad 4.6 \\
+73.9 \\
-51.0 \\
+20.0 \\
+33.3 \\
+\quad 0.8 \\
-22.8 \\
+13.7 \\
-\quad 8.0 \\
32.6 \\
+22.8 \\
-156.8 \\
-27.9 \\
-44.5 \\
+20.2 \\
-15.9 \\
+20.1 \\
+2.0 \\
-33.3 \\
-30.7 \\
-32.2 \\
+1.4 \\
+63.1 \\
-\quad 6.7 \\
+\quad 7.5\end{array}$ & $\begin{array}{r}-35.4 \\
+\quad 22.9 \\
+23.3 \\
-48.3 \\
+\quad 7.8 \\
+21.2 \\
+25.7 \\
+56.3 \\
+\quad 9.9 \\
+\quad 19.0 \\
-\quad 7.5 \\
+\quad 6.2 \\
+34.2 \\
-16.1 \\
-\quad 5.7 \\
-34.5 \\
+71.0 \\
+14.1 \\
+\quad 4.8 \\
-37.0 \\
-12.5 \\
-\quad 0.5 \\
+10.2 \\
+21.3 \\
+46.5 \\
+170.6 \\
+12.3 \\
+34.6 \\
+12.9 \\
+39.8 \\
+\quad 2.4 \\
+7.9 \\
+\quad 4.2 \\
+30.6 \\
+24.4 \\
+21.8 \\
+18.0 \\
+33.3 \\
+22.1\end{array}$ & $\begin{array}{r}-14.0 \\
-16.8 \\
-23.1 \\
-28.4 \\
+9.7 \\
-34.2 \\
+47.8 \\
+42.9 \\
+20.9 \\
-18.7 \\
-15.9 \\
-10.5 \\
+5.3 \\
+5.2 \\
+18.3 \\
+60.3 \\
-32.7 \\
-31.5 \\
+17.1 \\
+35.3 \\
-18.3 \\
+23.6 \\
+11.4 \\
+11.0 \\
+2.2 \\
+18.9 \\
-3.2 \\
+11.4 \\
-3.2 \\
+55.0 \\
-0.6 \\
-23.4 \\
-21.1 \\
+36.1 \\
-3.3 \\
+19.6 \\
-37.8 \\
+9.3 \\
+38.6\end{array}$ & $\begin{array}{r}-24.0 \\
+32.9 \\
-41.4 \\
+0.7 \\
+4.5 \\
-21.3 \\
-9.8 \\
-13.3 \\
-28.5 \\
-0.9 \\
-4.7 \\
+3.5 \\
-17.0 \\
-14.5 \\
+51.7 \\
+17.0 \\
+45.2 \\
+11.8 \\
-11.9 \\
+10.0 \\
-33.5 \\
-17.0 \\
+14.2 \\
-25.1 \\
+9.0 \\
-7.4 \\
+33.5 \\
-24.7 \\
+30.0 \\
+4.0 \\
+20.2 \\
+45.6 \\
+65.5 \\
+20.8 \\
-7.0 \\
+45.5 \\
+20.6 \\
-10.6\end{array}$ & $\begin{array}{r}+7.6 \\
+37.8 \\
-27.3 \\
+5.3 \\
+8.7 \\
-26.7 \\
+33.1 \\
+16.0 \\
+14.7 \\
+4.3 \\
-7.3 \\
-21.5 \\
-3.1 \\
-6.4 \\
-10.5 \\
-22.9 \\
-21.7 \\
+12.9 \\
+27.0 \\
-46.1 \\
+43.5 \\
+24.0 \\
+42.4 \\
+21.1 \\
-10.7 \\
-19.0 \\
+8.9 \\
+45.2 \\
-32.8 \\
0 \\
-18.5 \\
-2.4 \\
-2.3 \\
+23.4 \\
+10.6 \\
+49.2 \\
+5.9 \\
+17.6 \\
-2.3\end{array}$ & $\begin{array}{r}-31.6 \\
-41.7 \\
+41.4 \\
-27.0 \\
-19.7 \\
-21.4 \\
-6.4 \\
+23.7 \\
+26.6 \\
-2.6 \\
-14.8 \\
-4.7 \\
+11.4 \\
-17.1 \\
-22.5 \\
+1.7 \\
+2.3 \\
+30.0 \\
+0.7 \\
+23.4 \\
+32.3 \\
+3.6\end{array}$ & $\begin{array}{l}+1.8 \\
+27.8 \\
+13.2 \\
-35.1 \\
+4.5 \\
-26.4 \\
+15.2 \\
+15.7 \\
-28.5 \\
-4.2 \\
+3.4 \\
+6.2 \\
+3.0 \\
+7.1 \\
+21.3 \\
-16.5 \\
+34.7 \\
-14.3 \\
-33.8 \\
+6.4 \\
+10.3 \\
-6.1\end{array}$ \\
\hline
\end{tabular}

notes: $\quad$ \# not available

source: calculated from table 1

period 1961-70, and Table 2 shows these flows in terms of their percentage change from one year to the next.

The first noticeable feature is the considerable fluctuation in these gross inflows. The average annual shift in the flows to the 39 countries is 22.2 per cent. This was not a general shift associated with changes in the volume of total aid. It consisted of violent fluctuations on a country-by-country basis. The picture was hardly one of inertia.

Given the lack of stability there is a problem in defining what is to be regarded as a major change in the volume of aid received. Rather arbitrarily, we decided to concentrate on shifts of more than 40 per cent, either upwards or downwards, from one year to another. (At least from the recipient's point of view one would expect this to be 
regarded as a major variation). On this basis, 45 out of a total of 341 shifts can be regarded as major changes, although nine of these should perhaps be excluded since they occurred in the period 1961-63 in countries which were just beginning to receive substantial aid flows. A further ten are excluded to avoid double-counting due to the pipeline problem, where a sudden shift in commitments takes two years to work itself out into disbursements, or where a second shift reverses the direction of an increase or decrease back to the pre-shift level.

This leaves 26 major volume changes from one year to another, and it is possible to distinguish four patterns of aid inflow associated with them:

1. Short-term fluctuations from a continuing norm: the upward shift in the Dominican Republic in 1962 and three downward shifts - UAR in 1968, Afghanistan in 1962, and Argentina in 1968.

2. Shifts which set a new level of aid which was more or less sustained for at least the subsequent four years. Eleven of these are upward shifts - Ghana in 1965, Nigeria in 1964, Ceylon in 1966, Indonesia in 1967, Philippines in 1964, Malawi in 1964, Ethiopia in 1966, Congo (Zaire) in 1962, Peru in 1965, Iran in 1968, and Taiwan in 1967. Two are negative shifts - Iran in 1962 and UAR in 1965.

3. Eight shifts which were not followed by an immediate reversal, but where over the four subsequent years the volume either rose or fell back close to the pre-shift level. Upward shifts of this type occurred in Zambia in 1966, Guatemala in 1967, Bolivia in 1968, Chile in 1968 and Malaysia in 1968, while three downward shifts occurred, in Ethiopia in 1964, and in Mexico in 1962 and again in 1969.

4. One shift, in the Dominican Republic in 1965, stands on its own. Following a 71 per cent upward shift there is a 33 per cent fall-back in aid volume, and it is the level set then that is more or less sustained.

These disbursement patterns were checked against commitments to see if the categories remained demarcated (or if they were largely a function of the pipeline). When this was done, at least for the shifts which occurred after 1965 (no reliable and comparable commitment 
figures are available before that year), it became clear that no firm classification of patterns of aid inflow is really possible. Commitment behaviour is considerably more erratic than disbursement behaviour, and only two of the disbursement patterns remain.

On commitment figures there are considerably more large, single-year upward shifts followed by an immediate drop back in the level of commitments. This is not surprising, since a single-year commitment is often made to allow for a planned disbursement rate over a number of years. This is especially true of British aid, so that this type of pattern occurs clearly in Kenya, Malawi, Zambia and to some extent in Malaysia, although in the latter the addition of US assistance sustained the total commitment increase for a few years. Similar short-term increases also occurred in Chile in 1967, Guatemala in 1968, Ethiopia in 1966 and Peru in 1966. The only other disbursement category to reappear with commitment data is that of the large sustained shift, and the number of shifts which do fit into this category is reduced from thirteen to five - Ghana, Ceylon, Indonesia and Nigeria (with the exception of a major fall back in commitments in 1967) having sustained increases in aid volume, and UAR a sustained negative shift.

Sustained Aid Increases

The fact that this category, which corresponds with our initial hypothesis, turns out to include very few countries, is not very encouraging from the recipient's point of view, if we assume that most recipients have a concern to increase the amount of aid they receive and sustain this increase over time. Furthermore, a closer look at the circumstances associated with the shifts in this category reduces its general relevance still further. Three of the four shifts - those in Ghana, Ceylon and Indonesia - occurred in somewhat similar circumstances: each closely followed the establishment of new governments, considerably more pro-Western and less prone to radical rhetoric than their predecessors. Another feature the three countries had in common was that the advent of the new governments coincided with a major resource crisis in the form of an acute shortage of foreign exchange, and Indonesia and Ghana had, in addition, enormous and unpayable debts to many donors. (It is interesting to note that one of the earliest large and sustained increases in aid volume to an individual country, if we ignore strategic 
aid of the kind that was prevalent in the early 1950 s, occurred in 1958 in India, following that country's foreign exchange crisis). All three countries undoubtedly had a foreign exchange crisis prior to the election or coup which heralded the arrival of the new, favoured regime, but this had not resulted in substantial doses of foreign aid. This reinforces the picture presented in the existing static studies of aid distribution. It is almost a truism that economic arguments alone, in the absence of foreign policy considerations, will not cause aid to flow - and in these three countries it was the arrival of a new government, which donors had foreign policy reasons to support, rather than the foreign exchange crisis itself, that was the major impetus to the increased aid.

Several other characteristics were common to the situations of Ghana, Ceylon and Indonesia. The new governments in each case indicated their new political and foreign policy outlooks and their desire for assistance in their programmes of economic reorganization by actively seeking aid from Western donors and international organizations, all three embarking initially on stabilization programmes drawn up with the guidance of the IMF or World Bank, later followed by development programmes. Another common feature is the associated emphasis on 'planning' and the establishment or reorganization of central planning ministries for this purpose. A further common element is the emphasis by the new governments on new attitudes towards, and the encouragement of, foreign private investment. Whether or not action met words on this issue, this new emphasis, like the establishment of planning ministries, was clearly part of the public relations effort which attracted the support of Western donors. Not only did they get increased aid, but all three countries got a large proportion of programme aid designed to help them overcome their exchange crises. This was not achieved without a price - the attendant acceptance of the 'guidance' of the IMF or World Bank over economic policy-making is clearly apparent, even from the reports of these organizations, as was the tension created later when the donors wished to phase out programme assistance in favour of more project aid.

Nigeria does not fall into quite the same category, in that its increased aid level was not attendant upon a change of government and resource crisis, but rather accompanied the introduction of 
Nigeria's first National Development Plan (1962-68), which marked the commencement of Nigeria's extended search for external resources outside the established colonial relationship. The 1964 increase in aid indicated the Western donors' response to Nigeria's request, coupled with its attempt at coherent development planning. An additional cause of the donors' willingness to extend aid to Nigeria was undoubtedly the coincidental discovery of the wealth of Nigeria's natural resources, particularly its oil, and its encouragement of foreign private investment in extractive industries. Nigeria rapidly became the African 'success story' of the early 1960s.

One can only speculate on how much the donors' willingness to increase their aid to Nigeria was a result of Nigeria's 'good' economic management and how much of it was due to the discovery of Nigeria's resource endowment; but clearly the possession of resources of interest to donors; and the willingness to allow foreign business to exploit these resources, is a major advantage to recipients, if maximising aid is a desired goal. In this context, it is noticeable that of the other three countries in this category, only Indonesia is still sustaining large donor interests and ever-increasing aid flows, and only Indonesia has large quantities of valuable mineral resources and has actively encouraged a large increase in foreign private investment. $^{2}$

The DAC, in stating its inertia thesis, saw the resultant problem for the recipients as being their limited room for manoeuvre, it 'being largely limited to the increment in aid volume from one year to another' (DAC 1969 Review). But it would seem that the limitations are even greater. If it is true that the only countries which are likely to receive large and sustained increases in aid are those which are already in desperate trouble, and which have changed, either as a result of domestic upheavals resulting in a coup or through an election, to a government which has a political complexion more favoured by Western governments (or some of them) than its predecessor, and which is willing to implement policies favoured by those Western governments and accept substantial leverage over the direction of economic policy-making, or which are fortunate enough

\footnotetext{
${ }^{2}$ According to Indonesian figures, the inflow of foreign private capital increased from $\$ 17 \mathrm{~m}$ in 1969 to $\$ 137 \mathrm{~m}$ in 1970 .
} 
to possess vital natural resources, then the picture is far from encouraging. Few countries would go to the extreme of dislodging an existing government solely to increase their volume of external assistance, while the discovery of valuable natural resources is not something than can be engineered as part of a strategy for attracting resources. For most countries then, the likelihood of obtaining a major increase in aid would appear minimal, and of sustaining any increase that does occur, even remoter.

Mikesell, in discussing the geographical distribution of aid, concluded that, given the impossibility of discerning any economic rationale for the existing distribution of aid, and the difficulty of deciding upon a commonly agreed and accepted rationale for an alternative distribution, " . . donors should pay more attention to the allocation of aid for high priority and strategic purposes within countries, than to the allocation of aid among countries, as a means of maximising the impact of aid" (Mikesell, 1968). Such a conclusion, while appropriate, should perhaps be restated from the recipients' viewpoint. Given the lack of room for manoeuvre possessed by recipients in relation to the volume of aid they might receive, efforts geared to the allocation of aid for high priority and strategic purposes within their countries are more likely to be effective than efforts addressed to the volume as a means of maximising the impact of aid. It should be their priorities and their strategies they are concerned with, not those of the donors, either individually or collectively, and only in firmly establishing this will recipient countries have any room for manoeuvre. To put it more bluntly, a strategy of 'pleasing the donors' will not attract more aid. It will merely divert attention from the need to get the best value out of the amount of aid.

\section{Short-term Aid Increases}

In addition to these few sustained upward shifts, we have observed several large upward volume movements which were not sustained. Six countries received a disbursement increase of this sort - the Dominican Republic in 1962 with a one-year increase; and five Zambia in 1966, Guatemala in 1967, Bolivia in 1968, Chile in 1968, and Malaysia in 1968 - with slightly more sustained increases, but with the volume falling off again within three to four years. On commitment figures eight countries had large short-term upward shifts in volume in the period 1965-70 - Zambia in 1967, Guatemala 
in 1968, Chile in 1967, Kenya in 1967, Malawi in 1965, Ethiopia in 1966 and Peru in 1966 having one-year fluctuations, and Malaysia having an increase sustained for a three year period from 1966 to 1968. It is apparent that disbursement patterns in these countries are largely explained by the commitment trends, slow disbursements sustaining the increase, for instance in Malawi and Ethiopia, over at least four years, or faster disbursements causing annual receipts to fall back after two or three years, as in the Zambian or Chilean case. Hence, the discussion in this section should relate to commitment figures, and can refer only to movements after 1965, reliable commitment data not being available before then.

For those countries where the increase was largely a function of an increase in British aid there are relatively clear-cut explanations. The Kenyan, Malawian and Zambian increases were all the result of a large British commitment given to result in a planned disbursement rate. The Malawian increase coincided with the granting of independence and the breaking-up of the Central African Federation, whilst the Zambian increase was the result of a large British commitment following the Rhodesian Unilateral Declaration of Independence. In Kenya, British disbursements had been falling in the period 1965-67 due to a reduction in the scale of land transfer and resettlement and the fact that initial drawings under compensation and commutation loans were heaviest in the immediate post-independence years. The large 1967 commitment mostly consisted of a new $\$ 51$ million land transfer loan.

The initial increase in Malaysia is largely accounted for by an increase in US and Japanese commitments, the former rising from $\$ 4$ million to $\$ 41$ million, returning to around $\$ 6$ million in 1968 . The increase coincided with the introduction of Malaysia's new Five Year Plan (1966-70), which was accompanied by extensive efforts by Malaysia to increase its foreign borrowing for development financing. But the increase, unlike the similar increase in Nigeria, was not to be sustained, and the 1969 mid-term review of the Plan expresses disappointment at the failure to attract the amount of foreign resources envisaged by the Plan. Official documents at this time also stress the aid utilization problems that resulted from disbursement delays and the fact that the majority of offers were not aid but 
commercial credits. Only a large British commitment of $\$ 64.5$ million in 1968, which was special assistance in connection with the withdrawal of British forces from Malaysia, sustained the 1966 increase for a third year, the overall commitment level then falling sharply, from $\$ 80$ million in 1968 to $\$ 33$ million in 1969 .

Where the increase is largely a function of an increase in US aid, the explanations are often less obvious. This is partly because DAC commitment data are on a calendar year basis and do not always reflect trends accurately (US programmes are established on a fiscal year basis), and partly due to the way in which the USA often attempts to exert leverage through its aid commitments, which gives rise to very sharp short-term changes, induced by changes in US attitudes rather than by identifiable events. This is particularly true in Latin America where the tendency to support congenial governments through aid, and then withdraw support as governments repeatedly change, creates a confusing picture which is further compounded by disbursement delays: even if aid is cut off the amount in the pipeline usually remains usable, so that cut-offs and increases (because of disbursement delays) are often not manifested until sometime after the policy change, and often not at all.

\section{Aid Flows to Latin America}

Average annual fluctuations are considerably higher in Latin America than elsewhere. Whereas the annual average change in disbursements to the 39 major recipients for the period 1961-70 was 22.2 per cent, that to the ten Latin American countries amongst them was 27 per cent. On commitments, taking a slightly smaller sample of 25 countries, the overall annual average change from 1965 to 1970 was 38.7 per cent and for Latin American countries it was 42.5 per cent.

\footnotetext{
${ }^{3}$ Because of problems concerning the comparability of the data, analysis of the figures for commitments is confined to the following 25 countries: Ethiopia, Ghana, Kenya, Malawi, Morocco, Nigeria, Tanzania, UAR, Zaire, Zambia, Argentina, Bolivia, Braxil, Chile, Guatemala, Dominican Republic, Mexico, Peru, Afghanistan, Indonesia, Iran, Malaysia, Philippines, Sri Lanka, Taiwan. Others which could have been included on a comparable basis did not in fact experience large shifts in disbursements.
} 
The predominance of US flows to Latin American countries would suggest itself as an explanation, but raises the question whether it is because US aid flows are generally more volatile, or because US aid is more volatile in Latin America than elsewhere, or because the predominance of the US gave rise to exceptionally volatile flows from other donors.

Undoubtedly US aid is, on the whole, more dominant in Latin America than elsewhere, in the sense of constituting a greater proportion of total resource inflows. In our sample of 39 countries, on disbursement figures for 1961-70, US aid constituted an average of 53.1 per cent of the total aid flows to each country, ranging from a low of 8.1 per cent in Algeria and Malawi to 99.2 per cent in the Dominican Republic. The average proportion of US aid in the total flows to the ten Latin American countries was 80.5 per cent, only Argentina, Brazil, Mexico and Peru receiving less than this.

It will be recalled that the annual average shift in total flows to all 39 countries was 22.2 per cent and in the ten Latin American countries it was 27 per cent. The equivalent figures for the US alone are 30.2 per cent and 28.2 per cent respectively. This suggests: (i) overall, US aid flows are considerably more volatile than total flows, and (ii) in Latin America US flows are rather more stable than elsewhere, and only slightly more volatile than total flows.

But averages can be misleading, and a closer observation of US flows to the ten Latin American countries shows a major change in the middle of the decade. Until 1965 the average annual percentage change in the US flows to these ten countries was in each year considerably higher than it was to the other 29 countries. For each year from 1965 onwards the reverse was true - US flows to Latin America were far more stable than elsewhere, and between 1969 and 1970 the average change was only 12.9 per cent. In the second half of the 1960 s, the volatility of aid to Latin America was attributable to the behaviour of subsidiary donors:

Negative Shifts, Cut-offs and the Compensating Effect of Subsidiary Donors

The disbursement figures for the 39 countries indicate the occurrence of only a few large falls in aid volume, and particularly few 
large and sustained falls (see table 1). There are only two examples of the latter - in Iran after 1962 and UAR after 1965.

While there are only a very few examples of large downward movements in aid being sustained for a considerable period, there have been several sizeable cut-offs in aid from the major donor which have been compensated by an increase in aid from other sources. One implication of this is that major and sustained cut-offs, the threat or fear of which sometimes dominates the thinking of both donor and recipient agencies, has in fact occurred only rarely. A sustained decline in aid has not occurred as dramatically as many would see it, but rather more gradually, as in the decline of French aid to Algeria from 1964 or US aid to Taiwan in the early 1960s. One possible conclusion is that recipient countries could be less concerned with the possibility of a major suspension or decline of aid, which occurs relatively infrequently, and more concerned with attempting to diversify their sources of aid in a manner which ensures some regularity in inflows from secondary donors, and which may compensate for any decline that may occur in receipts from the primary donor.

\section{Multilateral and Bilateral Aid}

In general, according to DAC figures, the countries favoured by bilateral donors have also received relatively large amounts of aid per capita from multilateral agencies (DAC 1968 Review). To ascertain whether, within this general trend, movements in multilateral aid coincided with the bilateral pattern, an examination was made of the trends in the total amounts (as opposed to per capita amounts) of multilateral aid receipts in relation to the trends in bilateral receipts in. the 39 countries, and this revealed three main categories. This categorization encompasses 26 countries, 13 being excluded because of the relative unimportance of multilateral receipts in their total inflows. (India and Pakistan might have been excluded on these grounds, but have been included because of the large absolute amounts involved). Table 3 gives the gross multilateral disbursement figures for the 39 countries.

The largest category covers those countries in which multilateral receipts generally followed the same trend as bilateral receipts. The 
ten countries in this category are: Ethiopia, Ivory Coast, Cameroon, Colombia, Thailand, Nigeria, Tanzania, Iran, India, and Pakistan. In the first five of these countries both multilateral and bilateral receipts increased (with occasional exceptions) steadily from year to year throughout the decade. A similar pattem occurred in Nigeria, with the exception of a falling-off in multilateral receipts in 1969 and 1970, whilst bilateral receipts received a fresh impetus following the civil war. In Tanzania multilateral aid generally increased annually after 1964, whilst there was some fluctuation in bilateral receipts. The trend in the level of multilateral receipts in Iran closely follows the bilateral aid trend, first falling, then rising again from the middle of the decade. In India both trends are similar, both reaching a peak in 1967, then falling back during the rest of the decade. In Pakistan, multilateral receipts, like bilateral aid, rose in the early part of the decade, but the former reached their peak somewhat later - in 1967 , as compared with the bilateral peak in 1964.

table 3

Gross multilateral disbursements to 39 major recipients, 1961-70 US \$ million

\begin{tabular}{|c|c|c|c|c|c|c|c|c|c|c|}
\hline country & 1961 & 1962 & 963 & 1964 & 1965 & 1906 & 1967 & 1968 & 1969 & 1970 \\
\hline 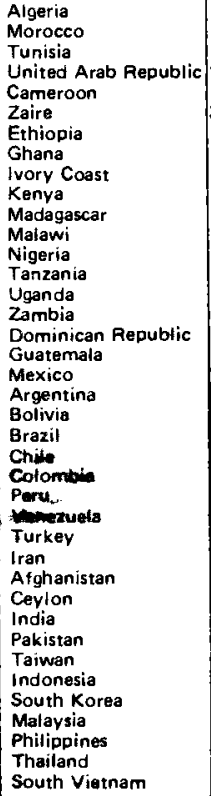 & $\begin{array}{r}0.01 \\
0.78 \\
0.85 \\
17.75 \\
0.65 \\
30.94 \\
3.59 \\
0.76 \\
2.37 \\
2.09 \\
1.44 \\
7 \\
4.85 \\
0.29 \\
4.13 \\
0.13 \\
0.15 \\
0.65 \\
12.14 \\
1.01 \\
3.12 \\
27.44 \\
9.02 \\
27.67 \\
11.02 \\
0.22 \\
1.38 \\
33.67 \\
1.62 \\
4.03 \\
75.02 \\
19.01 \\
0.47 \\
1.52 \\
0.23 \\
3.70 \\
2.13 \\
13.72 \\
0.55 \\
\end{array}$ & $\begin{array}{r}1.31 \\
1.82 \\
1.02 \\
26.36 \\
4.43 \\
6.72 \\
3.85 \\
1.05 \\
6.98 \\
2.88 \\
3.96 \\
0.03 \\
1.66 \\
3.06 \\
2.12 \\
0.21 \\
0.29 \\
1.54 \\
34.21 \\
28.65 \\
6.10 \\
26.11 \\
16.44 \\
40.69 \\
17.45 \\
2.14 \\
1.57 \\
37.67 \\
1.87 \\
6.70 \\
100.05 \\
22.26 \\
3.28 \\
1.45 \\
0.68 \\
10.72 \\
6.86 \\
18.88 \\
0.59\end{array}$ & $\begin{array}{r}5.05 \\
4.13 \\
3.42 \\
9.27 \\
5.43 \\
9.61 \\
5.03 \\
11.13 \\
7.14 \\
2.22 \\
7.99 \\
1 \\
4.30 \\
1.19 \\
3.06 \\
0.20 \\
0.98 \\
1.92 \\
100.06 \\
68.74 \\
6.86 \\
26.49 \\
24.38 \\
49.38 \\
18.67 \\
12.03 \\
2.90 \\
13.24 \\
1.99 \\
5.68 \\
114.97 \\
31.86 \\
5.07 \\
0.75 \\
13.39 \\
1.24 \\
11.45 \\
14.26 \\
0.44\end{array}$ & $\begin{array}{r}23.42 \\
4.94 \\
5.11 \\
10.12 \\
7.74 \\
19.70 \\
7.16 \\
17.71 \\
7.41 \\
2.82 \\
13.14 \\
0.22 \\
13.00 \\
4.18 \\
4.45 \\
0.32 \\
0.61 \\
1.25 \\
92.23 \\
56.92 \\
6.71 \\
27.69 \\
33.49 \\
72.24 \\
28.80 \\
32.50 \\
9.33 \\
6.46 \\
2.15 \\
4.10 \\
148.12 \\
36.70 \\
6.10 \\
3.38 \\
3.30 \\
18.45 \\
12.54 \\
17.71 \\
7 \\
\end{array}$ & $\begin{array}{r}2.32 \\
10.18 \\
5.15 \\
9.73 \\
13.10 \\
16.10 \\
13.13 \\
15.19 \\
11.25 \\
3.29 \\
12.90 \\
0.19 \\
28.14 \\
4.11 \\
3.06 \\
2.80 \\
0.88 \\
2.16 \\
46.92 \\
32.11 \\
7.00 \\
28.64 \\
39.43 \\
40.45 \\
27.98 \\
31.95 \\
13.03 \\
10.71 \\
2.76 \\
3.58 \\
246.77 \\
81.44 \\
13.72 \\
1.64 \\
2.39 \\
15.47 \\
21.43 \\
13.92 \\
1\end{array}$ & $\begin{array}{r}6.76 \\
16.11 \\
7.55 \\
2.99 \\
12.57 \\
6.17 \\
14.10 \\
7.76 \\
11.42 \\
12.85 \\
11.58 \\
0.74 \\
36.33 \\
6.39 \\
2.58 \\
2.53 \\
1.66 \\
2.74 \\
104.26 \\
19.09 \\
10.41 \\
42.69 \\
37.99 \\
62.35 \\
25.03 \\
57.25 \\
19.43 \\
20.88 \\
3.88 \\
2.85 \\
201.90 \\
88.51 \\
20.60 \\
0.35 \\
2.04 \\
24.59 \\
18.41 \\
24.01 \\
0.70\end{array}$ & $\begin{array}{r}6.75 \\
10.76 \\
7.83 \\
3.50 \\
10.61 \\
9.89 \\
11.66 \\
3.74 \\
8.22 \\
23.64 \\
13.05 \\
0.76 \\
39.51 \\
9.07 \\
2.31 \\
4.93 \\
3.37 \\
5.23 \\
90.89 \\
23.62 \\
7.01 \\
84.12 \\
31.68 \\
66.99 \\
30.99 \\
\mathbf{5 7 . 8 9} \\
\mathbf{2 2 . 9 7} \\
\mathbf{2 2 . 5 5} \\
5.33 \\
2.68 \\
276.19 \\
132.21 \\
9.13 \\
0.84 \\
2.81 \\
27.55 \\
21.16 \\
26.112 \\
0.62\end{array}$ & $\begin{array}{r}9.03 \\
15.75 \\
14.00 \\
9.32 \\
14.27 \\
10.90 \\
15.71 \\
3.25 \\
10.14 \\
22.11 \\
14.73 \\
3.11 \\
41.29 \\
8.36 \\
2.21 \\
5.51 \\
5.18 \\
4.01 \\
92.68 \\
36.16 \\
600 \\
90.50 \\
42.33 \\
69.24 \\
21.20 \\
62.98 \\
25.20 \\
26.42 \\
4.09 \\
2.24 \\
137.22 \\
120.73 \\
12.64 \\
9.04 \\
11.53 \\
27.62 \\
27.32 \\
36.79 \\
1.32\end{array}$ & $\begin{array}{r}16.64 \\
17.86 \\
18.64 \\
9.70 \\
11.76 \\
19.82 \\
18.63 \\
10.65 \\
13.77 \\
23.51 \\
17.88 \\
5.88 \\
34.57 \\
13.19 \\
9.62 \\
11.82 \\
12.85 \\
10.88 \\
138.21 \\
8.74 \\
10.16 \\
167.18 \\
44.38 \\
74.95 \\
2149 \\
30.37 \\
76.58 \\
28.14 \\
5.21 \\
5.49 \\
181.99 \\
98.26 \\
30.36 \\
14.34 \\
16.22 \\
21.06 \\
29.31 \\
46.64 \\
1.98\end{array}$ & $\begin{array}{r}20.14 \\
25.05 \\
18.58 \\
29.37 \\
18.32 \\
12.52 \\
7.64 \\
20.11 \\
22.96 \\
21.44 \\
10.69 \\
28.88 \\
13.96 \\
8.34 \\
8.52 \\
22.15 \\
12.56 \\
188.28 \\
80.41 \\
9.69 \\
185.42 \\
64.91 \\
113.09 \\
30.97 \\
30.08 \\
68.01 \\
36.34 \\
5.51 \\
7.84 \\
114.69 \\
107.86 \\
38.41 \\
15.19 \\
18.95 \\
24.93 \\
22.98 \\
40.74 \\
1.14\end{array}$ \\
\hline
\end{tabular}

sowrce: unpublished DAC material 
In the second category were eight countries -.. Kenya, Malawi, Zambia, Dominican Republic, Turkey, Madagascar, Taiwan and Ghana - where multilateral aid partly evened out the variations in bilateral receipts. The first five of these exhibit a similar pattern; that of multilateral aid receipts increasing considerably in the last two or three years of the decade, coinciding with a falling-off of bilateral receipts. In several instances the amount of multilateral aid in the first half of the decade was negligible or non-existent.

Another eight countries fall into a third category in which the trend in multilateral aid levels appears to be quite independent of the bilateral trend, neither complementing nor opposing it. With the exception of Malaysia, all countries in this category are Latin American - Guatemala, Brazil, Chile, Peru, Mexico, Argentina and Venezuela.

A more detailed analysis of the relationship between bilateral and multilateral receipts would be required in order to draw any firm conclusions about the balancing effect of multilateral aid in individual countries and its overall geographical distribution in relation to bilateral distribution. But this preliminary examination would seem to indicate that, at an individual country level, multilateral receipts tend on the whole to follow a similar trend to bilateral flows. This is in line with the DAC contention that multilateral flows generally fail to even out irregularities in bilateral flows, but the conclusion is weaker in relation to trends in absolute amounts and on an individual country basis than it is in relation to per capita receipts averaged over a period of time and on a global scale.

There were several examples of the level of multilateral aid rising as bilateral aid fell, and vice versa, and in Latin America in particular there was no evidence of a distinct relationship between bilateral and multilateral flows. A detailed analysis of the sources of multilateral aid, and, particularly in Latin America, of the relative contribution of IBRD and IDB, would be necessary to gain a complete picture. It has been suggested by some commentators ${ }^{4}$ that both these organizations are instruments of US policy. If this were true, one would

${ }^{4}$ Teresa Hayter, Aid as Imperialism, Penguin, 1971 , and numerous other writers of the same persuasion. 
expect receipts from them to exhibit a firm relationship to receipts from the US, but it appears in fact that receipts from the two institutions rarely fluctuate in the same direction as each other, or in any noticeable relationship to either total or US flows.

\section{Conclusions}

There are several conclusions about the geographical distribution of aid which are common to most writers on the subject, viz., that the existing distribution (i) is primarily based on a mixture of donor motives, particularly their political, historical, commercial and strategic interests in particular recipient countries; (ii) is therefore inequitable in terms of the wide disparities in per capita aid receipts; (iii) is 'irrational' in terms of being unrelated to any developmental or economic criteria; (iv) is statistically explicable only in terms of the small country effect.

While these conclusions seem solidly established, it is contended that the emphasis on the distribution issue, and attempts by economists to propound a more 'rational' distribution, is misplaced, and has given rise to what is likely to continue to be a fruitless search. Even if broad agreement were to be obtained that developmental criteria should be given greater, or even primary, consideration, there is little likelihood of agreement being reached on which criteria to adopt.

The DAC has perpetuated the belief that because the nondevelopmental links between donors and recipients are so strong, inertia is a major factor in maintaining the inequitable distribution that exists. While this is regrettable, it at least has the merit, the DAC would have us believe, of enabling recipient countries to predict the future volume of their aid receipts. To the extent that nondevelopmental links explain which groups of countries receive large inflows of aid from particular donors, and will continue to do so, the inertia thesis does have some applicability. However, it is much less applicable from the point of view of a developing country which is trying to forecast its aid receipts as a basis for drawing up a development programme.

The emphasis in previous studies on the stability and predictability of aid receipts due to inertia springs from their tendency to analyse the geographical distribution in terms of classes or groups of 
countries or regions, and the failure to recognise that the major allocation decisions made by donors are concerned with individual countries, rather than groups of countries. This study has attempted to analyse the changes that occur in the level of aid receipts of individual countries. Although the large fluctuations in receipts from year to year make it difficult to categorise countries into coherent groupings based on these changes, the exercise has led to a few broad conclusions about the nature of the distribution process.

The main conclusion concerns the very limited opportunities for recipients to increase the total volume of their aid receipts. Two main types of volume increase are observable -- a small number of sharp increases which occurred as a result of the donors' response to a specific internal situation, and which were sustained for some time; and a larger number of sharp increases which lasted for only a short time before the volume of receipts returned to its former level.

Both types of increase were usually the result of country-specific situations, usually more political than economic in nature, and contingent upon such factors as: replacement of a troublesome regime by a government deemed more co-operative with donor agencies (Ceylon, Indonesia, Ghana); approval by the donors of the policies of an incumbent regime (Ceylon, Indonesia, Ghana, Nigeria, Peru, Chile); some major disturbance, either domestic or external (Malaysia, Bangladesh, Malawi, Zambia); and the possession of valuable natural resources coupled with willingness to allow foreign exploitation of them (Indonesia, Nigeria, Chile). Some are also situations which are likely to change abruptly; for example, the disappearance of an approved government or a change in its policies may result in a rapid falling-off of the aid level, as occurred in Chile and Peru. Since these are events over which recipients have little control, and would rarely be fostered deliberately merely out of a desire to increase the amount of aid received, it would seem that the opportunities for recipients to exercise firm control over the level of aid, and to gain and sustain any substantial increase in that level, are minimal.

From the recipient viewpoint it is clear that there are major difficulties in devising a successful strategy to increase the aid 
volume, and it would seem that they should concentrate on a strategy related to the composition rather than the amount of aid, and concerned with the efficient allocation throughout their economy of the resources available. Strategies aimed at attracting more aid are less likely to repay the effort put into them than strategies aimed at attracting 'better' aid. 